\title{
Rhabditis spp., in the Espírito Santo, State of Brazil and evaluation of biological control
}

\author{
Rhabditis spp., no Espírito Santo, estado do Brasil e avaliação do controle biológico \\ Samilla Alves Sobral ${ }^{1}$; Bruna Silva Ferreira ${ }^{1}$; Caio Colodette Senna ${ }^{1}$; Carolina Magri Ferraz ${ }^{1}$; Tiago Facury Moreira ${ }^{2}$; \\ Otavio Luiz Fidelis Junior ${ }^{2}$; Emy Hiura ${ }^{1}$; Fernando Luiz Tobias ${ }^{3}$; Rosangela Zacarias Machado ${ }^{4}$; \\ Jackson Victor de Araújo ${ }^{5 *}$; Fabio Ribeiro Braga ${ }^{1}$ (D) \\ ${ }^{1}$ Laboratório de Parasitologia Experimental e Controle Biológico, Universidade Vila Velha - UVV, Vila Velha, ES, Brasil \\ ${ }^{2}$ Departamento de Clínica de Animais de Grande Porte, Universidade Vila Velha - UVV, Vila Velha, ES, Brasil \\ ${ }^{3}$ Laboratório de Microbiologia, Universidade Vila Velha - UVV, Vila Velha, ES, Brasil \\ ${ }^{4}$ Departamento de Patologia Veterinária, Faculdade de Ciências Agrárias e Veterinárias de Jaboticabal - FCAV, Universidade Estadual \\ Paulista Júlio de Mesquita Filho - UNESP, Jaboticabal, SP, Brasil \\ ${ }^{5}$ Laboratório de Parasitologia Veterinária, Departamento de Veterinária, Universidade Federal de Viçosa - UFV, Viçosa, MG, Brasil
}

Received October 24, 2018

Accepted March 21, 2019

\begin{abstract}
The objectives of this study were to describe occurrences of Rhabditis spp. causing parasitic otitis in dairy cattle of Gir breed in the state of Espírito Santo, southeastern Brazil, and to evaluate the biological control of this nematode using the nematophagous fungi Duddingtonia flagrans (AC001) and Monacrosporium thaumasium (NF34). After nematode detection and collection, three groups were formed: two groups that were treated, respectively, with the fungal isolates; and a control group, without fungus. The treatments were as follows: (a) Petri dishes containing the culture medium $2 \%$ water agar (WA) + 250 nematodes + AC001; (b) Petri dishes containing 2\% WA + 250 nematodes + NF34; and (c) Petri dishes containing only $2 \%$ WA +250 nematodes. After seven days at $27^{\circ} \mathrm{C}$ the treatments with fungi were able to capture and destroy the nematodes, with percentages of $82.0 \%$ (AC001) and 39.0\% (NF34) in relation to the control group. The results demonstrate the occurrence of Rhabditis spp. after animals physical examination and that there was efficacy of the in vitro predatory activity of both fungal isolates. Thus, these results are important because they can assist in future in vivo control of this nematode in cattle.
\end{abstract}

Keywords: Rhabditis spp., occurrence, production, nematophagous fungi, biological control.

\section{Resumo}

Os objetivos neste estudo foram descrever ocorrências do nematódeo Rhabditis spp., causando otite parasitária em bovinos leiteiros da raça Gir no estado do Espírito Santo, sudeste do Brasil, e avaliar o controle biológico desse nematódeo utilizando os fungos nematófagos Duddingtonia flagrans (AC001) e Monacrosporium thaumasium (NF34). Após a detecção e coleta dos nematódeos, três grupos foram formados: dois grupos que foram tratados com os isolados fúngicos, respectivamente; e um grupo controle, sem fungos. Os tratamentos foram os seguintes: (a) placas de Petri contendo o meio de cultura 2\% ágar de água (WA) + 250 nematoides + AC001; (b) placas de Petri contendo 2\% de $\mathrm{WA}+250$ nematoides + NF34; e (c) placas de contendo apenas $2 \%$ de nematódeos WA + 250. Após sete dias a $27^{\circ} \mathrm{C}$ os tratamentos com fungos foram capazes de capturar e destruir os nematódeos, com porcentagens de $82,0 \%$ (AC001) e 39,0\% (NF34) em relaçáo ao grupo controle. Os resultados demonstram a ocorrência de Rhabditis spp., no Estado do Espírito Santo e a eficácia da atividade predatória in vitro dos isolados fúngicos utilizados. Assim, esses resultados são importantes, pois podem auxiliar no controle alternativo in vivo de Rhabditis spp. em bovinos com otite parasitária.

Palavras-chave: Rhabditis spp., ocorrência, produção, fungos nematófagos, controle biológico. 


\section{Introduction}

Parasitic otitis may be caused by nematodes and mites, which may be associated with bacteria (BOSSI et al., 2015). The nematode responsible for the disease belongs to the genus Rhabditis, which affects both ears, producing cerulean or purulent exudates (BARBOSA et al., 2016). It has been reported that the occurrence of this disease in almost all regions of Brazil is well documented (DUARTE et al., 2001), and also in the state of Espírito Santo (BELTRAME et al., 2011).

Parasitic otitis is prevalent and has a negative impact on animal production. The disease becomes important because it leads to spending money on medications, that are sometimes ineffective, causes discomfort to the animals through intense pruritus and reduces their food consumption (MSOLLA et al., 1993). This condition results in decreased weight gain and loss of milk production, and may even lead to the animals' death (MSOLLA et al., 1987; DUARTE \& HAMDAN, 2004). The problems caused by this disease take on even greater magnitude when the economic importance of the dairy chain is considered.

Regarding biological control of this nematode, nematophagous fungi present predatory activity against nematodes, and this has been studied both under laboratory conditions and in the field (BRAGA \& ARAÚJO, 2014; SILVA et al., 2017a; ORTIZ PÉREZ et al., 2017; LUNS et al., 2018; FACCHINI et al., 2018). However, to the best of our knowledge, only one study on the predatory capacity of the fungal species Monacrosporium thaumasium against the nematode Rhabditis spp. has been published, showing successful in vitro control (ARAÚJO \& GUIMARÁES, 2002). Nematophagous fungi present themselves as natural enemies of gastrointestinal helminth parasites. They are divided into three groups (1) predators, (b) ovicidal and (c) endoparasites. Duddingtonia flagrans (predator) is an 'old friend' of scientists who envision biological control as an alternative to the treatment of herd animals by chemical means. This fungal is 'most promising' and its main activity culminates in the predation of infective helminth forms (in this case, nematode larvae), by simple adhesive hyphae (BRAGA \& ARAÚJO, 2014).

The aimed of the present study was to conduct an experimental assay with $D$. flagrans and $M$. thaumasium for biological control of Rhabditis spp..

\section{Materials and Methods}

The present experiment was approved by the Animal Ethics Committee of the Universidade Vila Velha under the process number 306 and was conducted on a dairy farm in the state of Espírito Santo located in the municipality of Guarapari City, at latitude $20^{\circ} 40^{\prime} 00^{\prime \prime} \mathrm{S}$ and longitude $40^{\circ} 29^{\prime} 51^{\prime \prime} \mathrm{W}$, in the southeastern region of Brazil. The climate of the regions is classified as Am (monsoon) according to Köppen's climate classification (ALVARES et al., 2013). The study occurred between May and June of 2018, corresponding to autumn. During this period, the average temperature, total precipitation and relative humidity were, $22{ }^{\circ} \mathrm{C}, 255 \mathrm{~mm}$ and was $85 \%$, respectively.
The total herd was composed by 200 animals, including cows, heifers, calves and bulls of Gyr and Girolando breeds. At total were used 13 Gyr cows between two and eight years old. Animals were kept in freestall and receive corn silage and concentrate.

Following the methodology adopted by Barbosa et al. (2016), with some modifications, the animals were restrained in an immobilizing "stock". Secretion present in the external auditory meatus (EAM) was collected with the swabs that consisted of a wooden stick with a tuft wrapped around the tip. The material removed was stored in polythene container. The EAM was then washed with $60 \mathrm{~mL}$ of saline solution. The washing solution was collected in a stainless-steel tray and then stored in $15 \mathrm{~mL}$ Falcon tubes. The material was transported at $8{ }^{\circ} \mathrm{C}$ in a thermal unit for further analysis.

The tubes containing washout were centrifuged and the content was separated using a Pasteur pipette. Saline solution was then added to the cotton tufts that had been stored in the universal collection tubes, so that the content could be decanted and subsequently processed. This was done in the same way as for the liquid from the washing. Parasites were detected through viewing the bronchoalveolar fluid on a slide, under an optical microscope at 10x magnification.

\section{Nematophagous fungi}

Two fungal isolates were used in the experiment: Duddingtonia flagrans (AC001) and Monacrosporium thaumasium (NF34). These isolates originated from Brazilian soil and came from the Parasitology Laboratory of the Federal University of Viçosa, where they were previously kept in test tubes at $4{ }^{\circ} \mathrm{C}$, containing $2 \%$ cornmeal agar ( $2 \% \mathrm{CMA}$ ) as the culture medium, in the dark, for 10 days. These fungi are registered in the National System of Genetic Heritage Management and Associated Traditional Knowledge.

After growth of the isolate, new culture plates of $4 \mathrm{~mm}$ in diameter were transferred to $9 \mathrm{~cm}$ Petri dishes containing $20 \mathrm{ml}$ of $2 \%$ water agar ( $2 \% \mathrm{WA})$, to which $1 \mathrm{ml}$ of distilled water containing 1000 larvae of Panagrellus sp. was added per day. The dishes were left for 21 days to induce formation of fungal conidia. When it was observed that fungal growth had been completed, $5 \mathrm{ml}$ of distilled water was added to each Petri dish, and the conidia and mycelial fragments were removed in accordance with the technique described by Araújo \& Guimarães (2002).

\section{Experimental assay}

After the nematodes had been obtained, three groups were formed: two groups that were treated with the fungal isolates; and a control group, without fungus. The treatments were as follows: (a) Petri dishes of $9.0 \mathrm{~cm}$ in diameter containing the culture medium 2\% WA + 250 nematodes + AC001; (b) Petri dishes of $9.0 \mathrm{~cm}$ in diameter containing $2 \% \mathrm{WA}+250$ nematodes + NF34; and (c) Petri dishes of $9.0 \mathrm{~cm}$ in diameter containing only 2\% WA + 250 nematodes (ARAÚJO \& GUIMARÁES, 2002).

Petri dishes were kept at $27^{\circ} \mathrm{C}$, for seven days. Every $24 \mathrm{~h}$, 10 random fields of each dish were observed with an light 
microscope with a $10 \times$ objective, and the number of non-preyed L3 was counted in each field.

After this period, the nematodes were recovered by Baermann funnel technique and were identified at genus level (UENO \& GONÇALVES, 1998; LEITE et al., 1994). The efficiency of $\mathrm{L}_{3}$ predation in relation to the control was assessed by percentage reduction in average $\mathrm{L}_{3}$ was then calculated using the formula described by Braga et al. (2009):

$$
\begin{aligned}
& \% \text { Reduction }=\text { ( } \mathrm{n} \text { from the } \mathrm{CG}- \\
& \mathrm{n} \text { from the TG) } \times 100
\end{aligned}
$$

$\mathrm{n}$ from the $\mathrm{CG}$

\section{Statistical analysis}

The results obtained were analyzed by means of analysis of variance (ANOVA) at the 5\% probability level. The Tukey test was applied as a post-assay test (AYRES et al., 2003).

\section{Results}

Animals were evaluated based on information collected during the visit. On physical examination, symptoms of shaking head, watery eyes, ear secretion, ranging from a mild to a severe, and apathy were noted in the five animals. Through analysis of otological material, the presence of the nematode Rhabditis spp. was performed.

In relation to the results from the in vitro biological control, both fungi were able to capture and destroy the nematode within seven days. Over these days, the final average reductions recorded were $82.8 \%$ for the isolate AC001 and $39.0 \%$ for the isolate NF34, both in relation to the control group $(\mathrm{P}<0.05)$. There was no difference $(\mathrm{P}>0.05)$ in means of non-predated Rhabditis spp., between the fungus isolates in each day (Table 1). Figure 1A presents the control group and Figure $1 \mathrm{~B}$ and $1 \mathrm{C}$ shows the capture and destruction of $\mathrm{L}_{3}$ by the isolates tested.

\section{Discussion}

Rhabditis spp. is the etiological agents most frequently found in parasitic otitis in cattle (DUARTE et al., 2001). There is only one report in the literature regarding biological control of this nematode using nematophagous fungi in vitro, in Brazil. The results of the present study demonstrated for the first time that AC001 had nematicidal activity on Rhabditis spp., destroying $82.8 \%$ of the nematodes at the end of seven days. On the other hand, NF34 isolate recorded a reduction of $39 \%$ at the end of

Table 1. Daily means and standard errors of non-predated of Rhabditis spp per 4-mm-diameter field in $2 \%$ water-agar during seven days in

\begin{tabular}{|c|c|c|c|c|c|}
\hline \multirow{2}{*}{ Days } & \multicolumn{5}{|c|}{ Treatments (means of non-predated of Rhabditis spp.) } \\
\hline & AC001 & NF34 & Control & \% Reduction - AC001 & \% Reduction - NF34 \\
\hline 1 & $6.2 \mathrm{a} \pm 0.85$ & $6.6 \mathrm{a} \pm 1.03$ & $11.3 \mathrm{~b} \pm 1.63$ & 45.1 & 41.6 \\
\hline 2 & $5.3 \mathrm{a} \pm 0.87$ & $5.7 \mathrm{a} \pm 1.01$ & $9.8 \mathrm{~b} \pm 1.36$ & 45.9 & 41.8 \\
\hline 3 & $4.6 \mathrm{a} \pm 1.09$ & $5.0 \mathrm{a} \pm 1.12$ & $9.3 \mathrm{~b} \pm 1.68$ & 50.5 & 46.2 \\
\hline 4 & $3.7 \mathrm{a} \pm 0.70$ & $4.9 \mathrm{a} \pm 0.98$ & $8.1 \mathrm{~b} \pm 1.72$ & 54.3 & 39.5 \\
\hline 5 & $2.5 \mathrm{a} \pm 0.55$ & $2.2 \mathrm{a} \pm 0.62$ & $9.8 \mathrm{~b} \pm 1.04$ & 74.5 & 77.6 \\
\hline 6 & $2.0 \mathrm{a} \pm 0.49$ & $1.7 \mathrm{a} \pm 0.66$ & $9.5 \mathrm{~b} \pm 1.31$ & 78.9 & 82.1 \\
\hline 7 & $1.3 \mathrm{a} \pm 0.40$ & $1.1 \mathrm{a} \pm 0.35$ & $6.8 b \pm 0.87$ & 80.8 & 83.8 \\
\hline
\end{tabular}
treatments with the fungal isolates Duddingtonia flagrans (AC001), Monacrosporium thaumasium (NF34) and control without fungus.

Means followed by the same small letter in the lines were not statistically different $(\mathrm{P}>0.05)$.

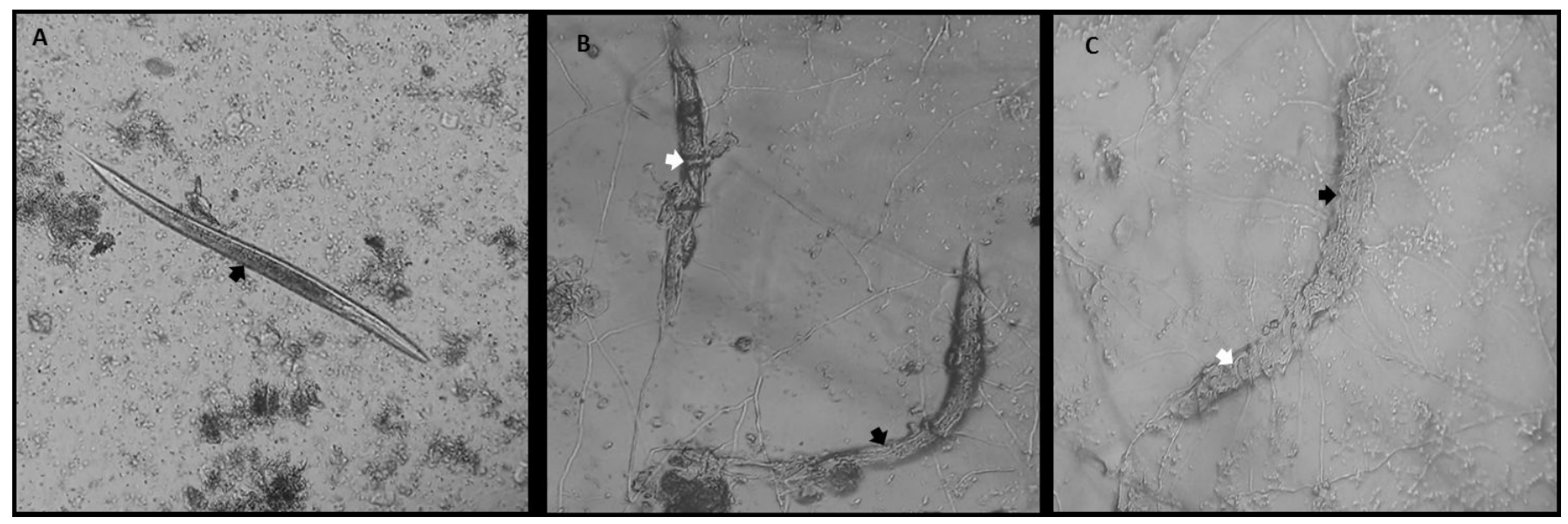

Figure 1. (A) control group. (B) Capture and destruction (white arrows) of Rhabditis spp. (black arrows) by nematophagous fungus Duddingtonia flagrans (AC001) and (C) capture and destruction (white arrows) of Rhabditis spp. (black arrows) by nematophagous fungus Monacrosporium thaumasium (NF34) throughout the experimental period. 
seven days. However, it should be mentioned that no difference ( $>$ > 0.05) was observed in the predatory activity among the fungal isolates used. Araújo \& Guimarães (2002) demonstrated that the NF34 on the second day of observation, captured all the nematodes. In the present study it was necessary to point out that our result was obtained after seven days of observation. This result corroborates the observations about the effectiveness of this isolate.

In the present study, the actions of capture and destruction performed by the AC001 and NF34 isolates together amounted $121.8 \%$ of reduction in the final average, thus proving that these isolates are efficient predators of Rhabditis spp. Along these lines, another recent study has demonstrated that nematophagous fungi may have an agonist effect (SILVEIRA et al., 2017). International literature on Rhabditis sp. biological control is sparse, with only a few reports on the activity of fungi on the $\mathrm{L}_{3}$ of this nematode. Rodríguez-Martínez et al. (2018) reported that the fungus Beauveria decreased the numbers of $\mathrm{L}_{3}$ by $71.9 \%$ after five days of interaction.

The proposed future use of biological controllers such as $D$. flagrans and $M$. thaumasium is based on their environmental presence on the form of chlamydospores and/or conidia, respectively, in greater abundance. These two fungi belong to the predator group, known as "helminthophages", providing the capture and destruction of the nematodes by modified hyphae (traps).

Throughout the experiment the reduction of the nematodes was observed, collaborating with this assertion, the in vitro studies with nematode parasites (BRAGA et al., 2009; LUNS et al., 2018). On the other hand, it should be pointed out that some nematodes may migrate to the periphery of Petri dishes, due to the higher humidity, which could cause their decrease (EREN \& PRAMER, 1965). However, in the present work the authors based on previous literature and carried out at the end of seven days the extraction of the nematodes from the treated groups and control by the Baermann method (BRAGA et al., 2014; SILVEIRA et al., 2017).

The nematode predatory action of the fungi $D$. flagrans and $M$. thaumasium has been extensively studied and proven in the literature (BRAGA \& ARAÚJO, 2014; BRAGA et al., 2009; LUNS et al., 2018; SILVA et al., 2017b). However, to the best of our knowledge, this is the first report to compare the activity of them over seven days of interactions on Rhabditis spp. Our aim, as the next scientific step, will be to test this activity in vivo experiments.

In an epidemiological survey in the state of Minas Gerais of 981 cattle examined, the Gir breed was the most prevalent with $60.1 \%$ of clinical otitis caused by Rhabditis spp., (DUARTE et al., 2001). On the other hand, there are no data on the epidemiology of this nematode in the state of Espírito Santo. There is only one report in the literature mentioning its occurrence (BELTRAME et al., 2011). In this way, the authors draw attention not only to the occurrence, but also to the biological control they propose. Vieira et al. (1998) mentioned in the in vitro experiment that Rhabditis spp., take seven to eight days to complete the biological cycle. In the present work, the reduction by field in the Petri dishes of the treated groups over seven days of observation (Table 1) was verified. In this sense, the results demonstrate that the biological control in vivo could be realized, starting from the premise of the evolutionary time of this nematode.
These alternative control actions are vitally important, since there is still a lack of elective protocols for chemical control over Rhabditis spp., and consequently over the cause of parasitic otitis. Thus, the results using nematophagous fungi are important as they may represent future alternatives for control of Rhabditis spp. in cattle in Brazil. To accomplish that, new studies in vivo with topical administration of the fungi are needed.

\section{Acknowledgements}

We gratefully acknowledge the financial contributions that were made by FAPES, CNPq and FAPEMIG. This study was financed in part by the Coordenação de Aperfeiçoamento de Pessoal de Nível Superior - Brasil (CAPES) - Finance Code 001”. We also thank Carolini Giacomim Pereira and Leticia Pereira Pedrini for their contributions. CNPq Scholarship Jackson Victor de Araújo.

\section{References}

Alvares CA, Stape JL, Sentelhas PC, Gonçalves JLM, Sparovek G. Köppen's climate classification map for Brazil. Meteorol Z 2013; 22(6): 711-728. http://dx.doi.org/10.1127/0941-2948/2013/0507.

Araújo JV, Guimarães MP. Ação do fungo predador de nematoides Monacrosporium thaumasium sobre Rhabditis spp. Ciênc Anim 2002; 12(2): 129-132.

Ayres M, Ayres JR, Ayres DL, Santos AS. BioEstat 3.0: aplicaçôes estatísticas nas áreas das ciências biológicas e médicas. Belém: Sociedade Civil Mamirauá; Brasília, D.F.: CNPq; 2003.

Barbosa JD, Silva JB, Lima DHS, Araújo LHV, Santos LL, Reis ASB, et al. Detection and treatment of otitis by Rhabditis blumi in cattle of northern Brazil. Pesq Vet Bras 2016; 36(7): 605-610. http://dx.doi.org/10.1590/ S0100-736X2016000700008.

Beltrame R, Suave Y, Sperandio B No, Diniz-Junior J, Cantareli P, Andriata L. Otite parasitária bovina no município de Colatina - ES. Vet Zootec 2011; 18: 904-906.

Bossi PV, Consoli EA, Rosa OL, Leite LB, Leite RC, Oliveira MG. Molecular identification and phylogenetic analysis of Metarhabditis blumi (Nematoda: Rhabditida). Vet Parasitol 2015; 214(1-2): 184-186. http:// dx.doi.org/10.1016/j.vetpar.2015.06.014. PMid:26464070.

Braga FR, Araújo JV, Silva AR, Araujo JM, Carvalho RO, Tavela AO, et al. Biological control of horse cyathostomin (Nematoda: Cyathostominae) using the nematophagous fungus Duddingtonia flagrans in tropical southeastern Brazil. Vet Parasitol 2009; 163(4): 335-340. http://dx.doi. org/10.1016/j.vetpar.2009.05.003. PMid:19497672.

Braga FR, Araújo JV. Nematophagous fungi for biological control of gastrointestinal nematodes in domestic animals. Appl Microbiol Biotechnol 2014; 98(1): 71-82. http://dx.doi.org/10.1007/s00253-013-5366-z. PMid:24265027.

Braga FR, Soares FEF, Araujo JM, Fonseca LA, Hiura E, Garschagen Gava $\mathrm{M}$, et al. Statistical experimental design to assess the influence of enzymes of nematophagous fungi versus helminths. Res Vet Sci. 2014; 97(3):527532. https://doi.org/10.1016/j.rvsc.2014.09.005. PMID: 25267285.

Duarte ER, Hamdan JS. Otitis in cattle, an aetiological review. J Vet Med B Infect Dis Vet Public Health 2004; 51(1): 1-7. http://dx.doi. org/10.1046/j.1439-0450.2003.00719.x. PMid:14995970. 
Duarte ER, Melo MM, Hamdan JS. Epidemiological aspects of bovine parasitic otitis caused by Rhabditis spp., and/or Raillietia spp., in the state of Minas Gerais, Brazil. Vet Parasitol2001; 101(1): 45-52. http://dx.doi. org/10.1016/S0304-4017(01)00492-7. PMid:11587832.

Eren J, Pramer D. The most probable number of nematode-trapping fungi in soil. Soil Sci 1965; 99(4): 285. http://dx.doi.org/10.1097/00010694196504000-00013.

Facchini JVRA, Braga FR, Campos AK, Carvalho LM, Araujo JM, Aguiar AR, et al. Duddingtonia flagrans formulated in rice bran in the control of Oesophagostomum spp. intestinal parasite of swine. Exp Parasitol 2018; 184: 11-15. http://dx.doi.org/10.1016/j.exppara.2017.11.001. PMid:29133187.

Leite RC, Leite RC, Faccini JLH. Diagnóstico e tratamento da otite parasitária por nematóides rhabditiformes em bovinos. Rev Bras Parasitol Vet 1994; 3(1): 69-70.

Luns FD, Assis RCL, Silva LPC, Ferraz CM, Braga FR, Araújo JV. Coadministration of nematophagous fungi for biological control over nematodes in bovine in the south-Eastern Brazil. BioMed Res Int 2018; 2018: 2934674. http://dx.doi.org/10.1155/2018/2934674. PMid:29780820.

Msolla P, Mmbuji WEO, Kasuku AA. Field control of bovine parasitic otitis. Trop Anim Health Prod 1987; 19(3): 179-183. http://dx.doi. org/10.1007/BF02239717. PMid:3660454.

Msolla P, Semuguruka WD, Kasuku AA, Shoo MK. Clinical observations on bovine parasitic otitis in Tanzania. Trop Anim Health Prod 1993; 25(1): 15-18. http://dx.doi.org/10.1007/BF02236880. PMid:8465437.

Ortiz Pérez DO, Sánchez Muñoz B, Nahed Toral J, Orantes Zebadúa MÁ, Cruz López JL, Reyes García ME, et al. Using Duddingtonia flagrans in calves under an organic milk farm production system in the Mexican tropics. Exp Parasitol 2017; 175: 74-78. http://dx.doi.org/10.1016/j. exppara.2017.02.009. PMid:28192084.

Rodríguez-Martínez R, Mendoza-de-Gives P, Aguilar-Marcelino L, López-Arellano ME, Gamboa-Angulo M, Rosas-Saito GH, et al. In vitro lethal activity of the nematophagous fungus Clonostachys rosea (Ascomycota: Hypocreales) against Nematodes of five different taxa. BioMed Res Int 2018, 1-7. https://doi.org/10.1155/2018/3501827.

Silva LPC, Oliveira JP, Keijok WJ, Silva AR, Aguiar AR, Guimarães MCC, et al. Extracellular biosynthesis of silver nanoparticles using the cell-free filtrate of nematophagous fungus Duddingtonia flagrans. Int $\mathrm{J}$ Nanomedicine 2017a; 12: 6373-6381. http://dx.doi.org/10.2147/IJN. S137703. PMid:28919741.

Silva ME, Uriostegui MA, Millán-Orozco J, Gives PM, Hernández EL, Braga FR, et al. Predatory activity of Butlerius nematodes and nematophagous fungi against Haemonchus contortus infective larvae. Rev Bras Parasitol Vet 2017b; 26(1): 92-95. http://dx.doi.org/10.1590/ s1984-29612016091. PMid:28146155.

Silveira WF, Braga FR, Tavela AO, Santos LF, Domingues RR, Aguiar AR, et al. Nematophagous fungi combinations reduce free-living stages of sheep gastrointestinal nematodes in the field. J Invertebr Pathol 2017; 150: 1-5. http://dx.doi.org/10.1016/j.jip.2017.08.013. PMid:28859879.

Ueno H, Gonçalves PC. Manual para diagnóstico das helmintoses de ruminantes. Tokyo: Japan International Cooperation Agency; 1998

Vieira MCM, Silva LAF, Borges NC, Araújo JLB, Santin API, Silva EV. Estudo da prevalência de otites clínicas por Rhabditis sp. em bovinos da raça Gir no Estado de Goiás. Anais Esc Agron Vet 1998; 28(2): 19-29. 